\title{
Correlation between clinical diagnosis and PCR analysis of serum, aqueous, and vitreous samples in patients with inflammatory eye disease
}

\author{
Correlação en tre o diagnóstico clínico e análise do PCR de amostras do soro, aquoso e \\ vítreoem pacientes com doença inflamatória ocular
}

\author{
Kimble Matos ${ }^{1}$ \\ Cristina Muccioli² \\ Rubens Belfort Junior ${ }^{3}$ \\ Luiz Vicente Rizzo ${ }^{4}$
}

\begin{tabular}{l} 
ABSTRACT \\
\hline Purpose: Tostudy the applicability (sensitivity, specificity) of polymerase \\
chain reaction (PCR) tests in the detection of cytomegalovirus (CMV), \\
herpes virus (HSV) and varicella zoster(VZV), Epstein-Barr virus (EBV), \\
Mycobacterium sp and Toxoplasma gondii in the diagnosis of patients \\
with or without AIDS, with presumably infectious uveitis, using serum, \\
aqueous humor and vitreous humor samples. Methods: Twenty individuals \\
with uveitis of presumed infectious origin were evaluated. Sixteen of them \\
had AIDS, four were immunocompetent individuals. We also evaluated 4 \\
normal controls who underwent vitrectomy surgery. Clinical evaluation of \\
the patients was performed together by three clinicians. PCR evaluations \\
of the serum, aqueous, and vitreous humor were performed in a masked \\
fashion by the laboratory staff. Results: Twelve patients had a clinical \\
diagnosis of CMV retinitis. Of these 6 (50\%) had a positive PCR for CMV \\
in the vitreous, three (25\%) had a positive PCR for CMV in the serum, and \\
none were positive in the aqueous. Five patients had a clinical diagnosis \\
of acute retinal necrosis (ARN). Three (60\%) of these had positive PCR for \\
HSV/VZV in the vitreous. One of these patients had a positive PCR reaction \\
for both EBV and HSV/VZV in the vitreous samples. One patient with \\
cutaneous herpes zoster had a positive PCR reaction for HSV/VZV in the \\
serum. Four patients had a presumed diagnosis of ocular toxoplasmosis, \\
one patient (25\%) had a positive PCR for Toxoplasma gondii in the serum, \\
3 (75\%) had positive results in the aqueous, and 2 (50\%) had positive \\
results in the vitreous. One patient with presumed ocular tuberculosis had \\
a positive PCR reaction both in the serum and in the vitreous samples. \\
Finally, none of the four control individuals revealed any positive PCR \\
reaction. Conclusion: PCR is an auxiliary diagnostic procedure that should \\
be evaluated together with ophthalmological aspects of the patient. \\
\hline
\end{tabular}

Keywords: Polymerase chain reaction; Uveitis; Inflammation; Eye diseases

\section{INTRODUCTION}

The clinical diagnosis of some uveitic disorders can be troublesome because of the lack of detectable systemic disease ${ }^{(1-5)}$. Clinical evaluation of patients may be further complicated because of vitreous opacities and vitreous haze which may confound fundoscopic examination ${ }^{(3)}$. Immunocompromised patients such as those with AIDS (acquired immunodeficiency syndrome) present additional problems for the clinical diagnosis of 
infectious uveitis because of the frequency of concomitant infections and the difficulty in obtaining reliable results for immunodiagnostic assays. In these patients, evaluating the presence of an infectious agent in ocular samples by molecular biology techniques can be a dependable alternative to conventional laboratory evaluation.

Toxoplasmosis is the most frequent cause of infectious uveitis in Brazil, occurring in approximately $30 \%$ of published series $^{(1-5)}$. Its typical presentation in immunocompetent hosts is easy to diagnose because of the characteristic atrophic lesions with hyperpigmented borders ${ }^{(6-7)}$. Atypical lesions have been reported more frequently and in immunocompromised individuals it may be especially difficult to establish a diagnosis based solely upon on the lesion's appearance.

Cytomegalovirus is the most frequent cause of infectious retinitis in patients with AIDS but is rare in immunocompetent individuals ${ }^{(4,8)}$. Introduction of new therapies, such as HAART (Highly Active Antiretroviral Therapy), can cause a dramatic change in the presentation of ocular CMV (cytomegalovirus) and make a clinical diagnosis more difficult. Herpetic uveitis may be caused by HSV (herpes simplex virus) types I and II and also by types IV and $\mathrm{V}^{(9-10)}$. The most common presentations of herpetic uveitis are acute retinal necrosis (ARN) $)^{(11)}$ or progressive outer retinal necrosis (PORN), which are mainly described in AIDS patients ${ }^{(12)}$. The ocular manifestations of herpes infection in AIDS patients may occasionally be confused with those of CMV and Toxoplasma gondii and concomitant infection by these agents cannot always be ruled out ${ }^{(6,9,13)}$.

Ocular Mycobacterium infection presents a wide range of clinical manifestations which may be confused with other infectious diseases as well as with non-infectious uveitis ${ }^{(2,14)}$. Although it is part of the differential diagnosis of uveitis in immunocompromised hosts in Brazil, despite the high incidence of pulmonary tuberculosis reports of ocular disease are $\operatorname{rare}^{(14-15)}$.

Additionally, other causes of uveitis in AIDS patients must be considered, among them Mycobacterium avium, Treponema pallidum, Cryptococcus neoformans, and Pneumocystis carinii $^{(13,15)}$.

Due to the rapidly progressive course that retinitis, e.g. ARN, may take in immunocompromised patients, a rapid diagnosis is paramount to avoid loss of vision. Many complementary laboratory tests are available to assist in the diagnosis of the above mentioned diseases ${ }^{(16-19)}$. Aside from the inherent problems any laboratory test may have, all the tests available for the diagnosis of infectious uveitis in individuals with AIDS are complicated by the immune status of the patient. We decided to test the efficacy of PCR for the detection of these parasites. Advantages of PCR as a diagnostic test are its ability to analyze minute samples, the rapidity with which results can be obtained and because its performance is not altered by the immune response of the patient.

The objective of this study is the applicability (sensitivity, specificity) of polymerase chain reaction (PCR) tests in the detection of cytomegalovirus (CMV), herpes virus (HSV) and varicella zoster (VZV), Epstein-Barr virus (EBV), Mycobacterium sp and Toxoplasma gondii in the diagnosis of patients with or without AIDS, with presumably infectious uveitis, using serum, aqueous humor and vitreous humor samples.

\section{METHODS}

Twenty patients were selected from the Uveitis Service at "Escola Paulista de Medicina", Brazil, 16 with uveitis and HIV infection, 4 with uveitis without HIV infection. The mean age of the patients was 37 (range 24-57); 16 were male and 4 female in a group of patients with uveitis, and 3 male and one female in the control group. The average of onset of ocular disease was 12.5 months (range 6-48 months) prior to PCR testing. Four patients underwent intravitreal therapy with formivirsem, one with ganciclovir, one with a ganciclovir implant, 8 with IV ganciclovir ( $5 \mathrm{mg} / \mathrm{kg} /$ day), 4 with acyclovir $800 \mathrm{mg} /$ day, 3 with pyrimethamine plus sulfadiazine $(25 \mathrm{mg} /$ day $+4 \mathrm{~g} /$ day respectively) and one with no systemic treatment. None of patients displayed associated other systemic infectious disease with the exception of the HIV infection when it was the case. Eighteen patients underwent vitrectomy due to retinal detachment, and 2 had vitreous aspiration. Tables 1, 2 and 3 summarize the comparisons between clinical diagnosis and PCR results in the AIDS patients, immunocompetent and controls respectively.

Informed consent was obtained from each patient who received detailed explanation of all the procedures involved as part of the study. The study protocol had the approval of the review board of the Ethics Committee of the "Escola Paulista de Medicina".

The diagnosis of uveitis was based on the clinical characteristics according to the criteria established by the International Uveitis Study Group and the Research Committee of the American Uveitis Society ${ }^{(20-21)}$.

Sample preparation. Serum, aqueous and vitreous samples from 20 patients with uveitis of presumed infectious etiology were collected, of whom 16 patients had AIDS and 4 did not. The control group consisted of 4 patients who underwent vitrectomy; one for treatment of a macular hole, 2 patients for retinal detachment repair, and one for dislocation of an intraocular lens into the vitreous. Samples were stored at $-20^{\circ} \mathrm{C}$ until use for nucleic acid extraction.

PCR Analysis. DNA was isolated from the samples according to the method described by Boom et al ${ }^{(22)}$. Primers for CMV, HSV/VZV (herpes simplex virus/varicella zoster virus), EBV(Epstein-Barr virus), Toxoplasma gondii and mycobacteria were selected from published sequences ${ }^{(23-25)}$. Primers were tested for optimal anneling temperature and $\mathrm{Mg}^{2+}$ concentration as described before ${ }^{(26)}$. Uracyl-DNA glycosylase was used to control carry-over contamination ${ }^{(27)}$. The amplification mixture contained $0.4 \mathrm{pmol} 3$ ' and 5 ' primers and $0.2 \mathrm{mmol}$ dNTP (Life Technologies, Grand Island, NY, USA), 0.1 U Taq Gold polymerase (Perkin-Elmer, CA, USA), 0.1 U uracyl DNA glycosylase and $5 \mu \mathrm{l}$ DEPC water. The primer's sequences are detailed in table 4. PCR reactions were performed in a Gene- 


\begin{tabular}{|c|c|c|c|c|}
\hline Patient & Diagnostic hypothesis & Serum & Aqueous & Vitreous \\
\hline 1 & ARN & Negative & Negative & EBV/HSV/VZV \\
\hline 2 & ARN & EBV & Negative & HSV/VZV \\
\hline 3 & ARN & CMV & Negative & HSV/VZV \\
\hline 4 & $A R N+T O X O$ & Negative & TOXO & Negative \\
\hline 5 & CMV & Negative & Negative & Negative \\
\hline 6 & CMV & Negative & Negative & Negative \\
\hline 7 & CMV & Negative & Negative & Negative \\
\hline 8 & CMV & Negative & Negative & Negative \\
\hline 9 & CMV & Negative & Negative & CMV \\
\hline 10 & CMV & Negative & Negative & CMV \\
\hline 11 & CMV & Negative & Negative & CMV \\
\hline 12 & CMV & HSV/VZV & Negative & Negative \\
\hline 13 & CMV & CMV/EBV TOXO & Negative & CMV \\
\hline 14 & CMV & CMV/EBV & Negative & $\mathrm{CMV} / \mathrm{HSV} / \mathrm{VZV}$ \\
\hline 15 & CMV & CMV & Negative & CMV \\
\hline 16 & $\mathrm{TOXO}+\mathrm{CMV}$ & EBV/TOXO & TOXO & Negative \\
\hline
\end{tabular}

\begin{tabular}{|c|c|c|c|c|}
\hline Patient & $\begin{array}{l}\text { Diagnostic } \\
\text { hypothesis }\end{array}$ & Serum & Aqueous & Vitreous \\
\hline 1 & ARN & Negative & Negative & Negative \\
\hline 2 & TB & MB & Negative & $\mathrm{MB} / \mathrm{TOXO}$ \\
\hline 3 & TOXO & Negative & Negative & TOXO \\
\hline 4 & TOXO & Negative & TOXO & TOXO \\
\hline
\end{tabular}

ARN: acute retinal necrosis; TB: tuberculosis; TOXO: toxoplasmosis; MB: mycobacteriosis

\begin{tabular}{|c|c|c|c|c|}
\hline Patient & $\begin{array}{l}\text { Diagnostic } \\
\text { hypothesis }\end{array}$ & Serum & Aqueous & Vitreous \\
\hline 1 & Control & Negative & Negative & Negative \\
\hline 2 & Control & Negative & Negative & Negative \\
\hline 3 & Control & Negative & Negative & Negative \\
\hline 4 & Control & Negative & Negative & Negative \\
\hline
\end{tabular}

Amp 2400 PCR system thermal cycler (Perkin-Elmer) as follows: samples were incubated for $10 \mathrm{~min}$ at $37^{\circ} \mathrm{C}$ and afterwards at $95^{\circ} \mathrm{C}$ for 5 minutes, then 40 cycles were performed consisting of 1 minute at $95^{\circ} \mathrm{C}$ (denaturation), 1 minute at the optimal anneling temperature (varied from primer to primer) and 1.5 at $72^{\circ} \mathrm{C}$ (elongation). After the last cycle, samples were incubated for 7 minutes at $72^{\circ} \mathrm{C}$ for final elongation. One fifth of the PCR was analysed on a $1.8 \%$ agarose gel, stained with ethidium bromide and photographed. Positive results were evaluated by length of the analyzed product against a molecular weight marker and against a positive control. All PCR reactions were read by one of us (LVR) in a masked fashion.

Descriptive statistically analysis was performed due to little number of patients, therefore further conclusions with statistical power was unreachable.

\section{RESULTS}

Eighteen of the patients presented only one diagnostic hypothesis, and the other two patients presented a combination of two diagnoses. Three patients had a positive PCR for Toxoplasma gondii in the aqueous, all other individuals had

\begin{tabular}{|c|c|c|}
\hline Primers & Sense & Antisense \\
\hline Cytomegalovirus & TGAGGATAAGCGGGAGATGT & ACTGAGGCAAGTTCTGCAGT \\
\hline Epstein-Barr Virus & СTСTСTСTGTССTTCAGAGG & GTGGCTCCCCTCAGACATTC \\
\hline $\begin{array}{l}\text { Herpes simplex Virus } \\
\text { Varicella Zoster Virus }\end{array}$ & ATCACGGTAGCCCGGCCGTGTGACA & CATACCGGAACGCACCACACAA \\
\hline Toxoplasma gondii & TCTTTAAAGCGTTCGTGGTC & GGAACTGCATCCGTTATGAG \\
\hline Mycobacterium $s p$ & CACATGCAAGTCGAACGGAAAGG & GCCCGTATCGCCCGCACCCTCACA \\
\hline
\end{tabular}


negative PCR results for aqueous samples. Of the 12 individuals with a putative diagnosis of CMV retinitis, $6(50 \%)$ had a positive PCR for CMV in the vitreous. Three of these patients also had positive PCR reactions for CMV in the serum. Sensitivity in the serum and vitreous were $25 \%$ and $50 \%$ respectively, and the specificity in the serum and vitreous were $87.5 \%$ and $100 \%$ respectively.

When we compared the two groups regarding accuracy of diagnosis in vitreous samples, in the group with AIDS the diagnosis was confirmed in $9(56 \%)$ of 16 patients, while in the immunocompetent group the diagnosis was made in $3(75 \%)$ of 4 patients. Of the five individuals with a clinical diagnosis of ARN, $3(60 \%)$ had a positive HSV/VZV PCR in the vitreous. One case also had a positive EBV PCR in the vitreous, and this case had the worst outcome, becoming blind in both eyes within two months despite aggressive therapy. Another individual had a positive PCR for EBV in the serum but vitreous PCR was positive for HSV/VZV, and another was positive for CMV in the aqueous sample but vitreous PCR samples showed positive HSV/VZV PCR. Concomitant infections are common in AIDS, and often PCR testing of serum will reveal them; thus the serum results may not always represent correctly the infectious picture in the eye. Interestingly, one of the individuals with a putative diagnosis of ARN had toxoplasmosis as a differential diagnosis, however aqueous PCR was positive only for toxoplasmosis. The sensitivities for toxoplasmosis in aqueous and vitreous were 75 and $50 \%$ respectively, and the specificities in aqueous and vitreous were 100 and $93.7 \%$ respectively. Once more the accuracy of using PCR as a diagnostic method when we compared the two groups with and without AIDS was markedly distinct. In the two AIDS patients who were PCR positive in the aqueous, PCR confirmed the clinical diagnosis which in these cases was doubtful. In the group without AIDS there were 3 PCR positive vitreous samples, and one aqueous samples. Ocular toxoplasmosis was a clinical diagnosis or was part of the differential diagnosis in four patients. All four had positive PCR reactions for toxoplasmosis. One of them, cited above, was positive only in the aqueous samples. Another was positive in the aqueous and serum samples; this patient was also considered for CMV retinitis but CMV was not detected in any of the samples. However, EBV was detected in the serum of this patient.

Table 2 clearly shows that PCR was negative for all four control patients. Finally, two other patients had a positive PCR result for toxoplasmosis in the vitreous, once again confirming the clinical diagnosis.

The only patient with a putative diagnosis of ocular tuberculosis had a positive result for mycobacteriosis both in the serum and in the vitreous.

\section{DISCUSSION}

McCann et al. ${ }^{(28)}$, studied patients with CMV retinitis through PCR analysis and reported that sensitivity of PCR in treated patients was $48 \%$, compared with $95 \%$ in non-treated patients. All of our patients were treated; thus we cannot make any comparison between treated and non-treated groups.

In spite of several reports demonstrating a positive PCR analysis in aqueous humor specifically for herpes virus infection $^{(29-34)}$, we found no positivity in aqueous samples. Meanwhile we found a positive PCR analysis in vitreous samples in three cases in a total of 5 cases of presumptive ARN. Therefore we conclude in our study that PCR analysis for these cases were more helpful when analyzed in vitreous samples.

Wiedbrauk et $\mathrm{al}^{(35)}$, reported an inhibitory effect in PCR analysis of aqueous and vitreous, however in our study of the PCR analysis we found no evidence of this inhibitory effect; when PCR result was positive it confirmed the clinical diagnosis.

Chodosh ${ }^{(36)}$, detected EBV DNA in cadaveric ocular tissue at apparently normal ocular sites which raises the possibility of viral involvement, but emphasizes the need for specific criteria to implicate EBV in ocular pathology. In our study we found EBV in vitreous associated with HSV/VZV in a severe case of acute retinal necrosis, and in 4 patients whose sera was positive for EBV, [all were HIV positive, 2 with CMV retinitis, one with acute retinal necrosis, and an other with a clinical diagnosis of CMV and toxoplasmosis]. None of the control group samples showed any evidence of EBV in sera, aqueous or vitreous.

The confirmation of clinical diagnosis is highest in PCR of vitreous samples. In CMV retinitis and ARN, the positivity of the PCR analysis in vitreous was $50 \%$ and $60 \%$ respectively, in toxoplasmosis it was $50 \%$, and in our only patient with mycobacteriosis, the accuracy was $100 \%$.

In patients with acute retinal necrosis, two of them had positive PCR results more than 3 months after onset the disease, and the other two had positive PCR result one month after the onset of the disease. In our study, duration of the disease did not interfere with the result of PCR analysis, in spite of the conclusions reached by de Boer et al. ${ }^{(37)}$. There is a good correlation between clinical diagnosis and PCR amplification of infectious DNA from vitreous.

\section{CONCLUSIONS}

Which can be drawn from this study include the following: A- PCR exam is a auxiliary diagnostic procedure that should be evaluated with ophthalmological aspects of the patient. B- PCR exam showed in the serum, with exception of ocular toxoplasmosis (25\%) and CMV (25\%), with a very low sensitivity, in this way it was not indicated as a diagnostic procedure. C- PCR exam in the aqueous humor, was precise only in ocular toxoplasmosis, with a sensitivity of $75 \%$. D- PCR exam in the vitreous was more helpful as an auxiliary diagnostic test in the cases of CMV and ARN than PCR test of serum and aqueous. E- The time of the onset of the disease in our study did not appear to influence the results of the PCR analysis. F- Quality control of collection and analysis samples for PCR analysis should be high in order to avoid contamination and false positive results. 


\section{RESUMO}

Objetivos: Avaliar a aplicabilidade (especificidade, sensibilidade) do teste da reação da cadeia de polimerase (PCR) na detecção de citomegalovírus (CMV), herpes vírus e varicela zoster (HSV, VZV), Epstein-Barr vírus (EBV), Mycobacterium sp e Toxoplasma gondii no diagnóstico de pacientes com ou sem AIDS, com uveíte infecciosa presumível, utilizando amostras de humor aquoso, humor vítreo e soro. Métodos: Vinte pacientes com uveíte infecciosa presumível foram estudados. Dezesseis destes apresentavam AIDS e quatro eram imunocompetentes. Foram utilizados quatro pacientes como grupo controle que se submeteram a vitrectomia. A avaliação clínica foi feita conjuntamente com três oftalmologistas. O exame do PCR do soro, aquoso e vítreo foi feito sem o conhecimento da hipótese diagnóstica pela equipe do laboratório. Resultados: Doze pacientes tinham o diagnóstico clínico de retinite por CMV. Deste subgrupo $6(50 \%)$ eram PCR positivo para CMV no vítreo, 3 (25\%) eram PCR positivos para CMV no soro e nenhum destes foi positivo no aquoso. Cinco pacientes tinham o diagnóstico clínico de necrose aguda de retina (ARN). Três $(60 \%)$ destes eram PCR positivos para HSV/VZV no vítreo. Um destes pacientes era PCR positivo tanto para EBV e HSV/VZV na amostra do vítreo. Um destes pacientes com herpes zoster cutâneo era PCR positivo para HSV/VZV no soro. Quatro pacientes tinham o diagnóstico de toxoplasmose ocular presumida, um paciente $(25 \%)$ era PCR positivo para Toxoplasma gondii no soro, 3 (75\%) eram positivos no aquoso e $2(50 \%)$ eram positivo no vítreo. Um paciente com tuberculose ocular presumível era PCR positivo tanto no soro quanto no vítreo. Nenhum dos pacientes do grupo controle era PCR positivo em qualquer amostra. Conclusão: O exame do PCR é procedimento diagnóstico auxiliar que deve ser utilizado conjuntamente com os aspectos clínicos.

Descritores: Reação em cadeia da polimerase; Uveíte; Inflamação; Oftalmopatias

\section{REFERENCES}

1. Orefice F, Belfort Jr R. Uveites. São Paulo: Roca; 1987.

2. Belfort Jr R, Couto CA, Castro FM. Uveites: Sinopsis diagnostica y terapeutica. Buenos Aires: Ciba Vision; 1997.

3. Abreu MT, Hirata PS, Belfort Jr R, Domingues Neto S. Uveítes em São Paulo: estudo epidemiológico, clínico e terapêutico. Arq Bras Oftalmol. 1980;43(1):10-6.

4. Muccioli C, Belfort Júnior R, Lottenberg C, Lima J, Santos P, Kim M, et al. Achados oftalmológicos em AIDS: avaliação de 445 casos atendidos em um ano. Rev Assoc Med Bras (1992). 1994;40(3):155-8.

5. Nussenblatt RB, Whitcup SM, Palestine AG. 2nd ed. Uveitis: fundamentals and clinical practice. St. Louis: Mosby; c1996.

6. De Smet MD. Differential diagnosis of retinitis and choroiditis in patients with acquired immunodeficiency syndrome. Am J Med. 1992;92(2A):17S-21S. Review.

7. Holland GN, O'Connor GR, Belfort R Jr, Remington JS. Toxoplasmosis. In: Pepose JS, Holland GN, Wilhelmus KR, editors. Ocular infection and immunity. St. Louis: Mosby; 1996. p.1183-223.

8. Holland GN, Tufail A, Jordan MC. Cytomegalovirus diseases. In: Pepose JS,
Holland GN, Wilhelmus KR, editors. Ocular infection and immunity. St. Louis: Mosby; 1996. p.1088-129.

9. Margolis TP, Atherton SS. Herpes simplex virus diseases: posterior segment of the eye. In: Pepose JS, Holland GN, Wilhelmus KR, editors. Ocular infection and immunity. St. Louis: Mosby; 1996. p.1155-68.

10. Culbertson WW, Blumenkranz MS, Pepose JS, Stewart JA, Curtin VT. Varicella zoster virus is a cause of the acute retinal necrosis syndrome. Ophthalmology. 1986;93(5):559-69.

11. Clarkson JG, Blumenkranz MS, Culbertson WW, Flynn HW Jr, Lewis ML. Retinal detachment following the acute retinal necrosis syndrome. Ophthalmology. 1984;91(12):1665-8.

12. Sato EH, Machado VHT, Farah Neto ME, Abreu MT, Belfort Jr R. Necrose aguda de retina. Rev Bras Oftalmol. 1985;44(1):28-31.

13. Newman NM, Mandel MR, Gullett J, Fujikawa L. Clinical and histologic findings in opportunistic ocular infections. Part of a new syndrome of acquired immunodeficiency. Arch Ophthalmol. 1983;101(3):396-401.

14. Oréfice F, Carvalho AZ, Pinheiro SRA. Controvérsias nas uveítes tuberculosas. Arq Bras Oftalmol. 1987;50(6):237-45.

15. Muccioli C, Belfort R Jr. Presumed ocular and central nervous system tuberculosis in a patient with the acquired immunodeficiency syndrome. Am J Ophthalmol. 1996;121(2):217-9.

16. Mitchell SM, Fox JD. Aqueous and vitreous humor samples for the diagnosis of cytomegalovirus retinitis. Am J Ophthalmol. 1995;120(2):252-3.

17. Davis JL, Feuer W, Culbertson WW, Pflugfelder SC. Interpretation of intraocular and serum antibody levels in necrotizing retinitis. Retina. 1995;15(3): 233-40.

18. Paya CV, Smith TF, Ludwig J, Hermans PE. Rapid shell vial culture and tissue histology compared with serology for the rapid diagnosis of cytomegalovirus infection in liver transplantation. Mayo Clin Proc. 1989;64(6):670-5.

19. Schmitt-Graff A, Neuen-Jacob E, Rettig B, Sundmacher R. Evidence for cytomegalovirus and human immunodeficiency virus infection of the retina in AIDS. Virchows Arch A Pathol Anat Histopathol. 1990;416(3):249-53.

20. Bloch-Michel E, Nussenblatt RB. International Uveitis Study Group recommendations for the evaluation of intraocular inflammatory disease. Am J Ophthalmol. 1987;103(2):234-5.

21. Holland GN. Standard diagnostic criteria for the acute retinal necrosis syndrome. Executive Committee of the American Uveitis Society. Am J Ophthalmol. 1994;117(5):663-7.

22. Boom R, Sol CJ, Salimans MM, Jansen CL, Wertheim-van Dillen PM, van der Noordaa J. Rapid and simple method for purification of nucleic acids. J Clin Microbiol. 1990;28(3):495-503.

23. Mahalingam R, Wellish M, Wolf W, Dueland AN, Cohrs R, Vafai A, Gilden D. Latent varicella-zoster viral DNA in human trigeminal and thoracic ganglia. N Engl J Med. 1990;323(10):627-31.

24. Nahass GT, Goldstein BA, Zhu WY, Serfling U, Penneys NS, Leonardi CL. Comparison of Tzanck smear, viral culture, and DNA diagnostic methods in detection of herpes simplex and varicella-zoster infection. JAMA. 1992;268 (18):2541-4.

25. Cathomas G, Morris P, Pekle K, Cunningham I, Emanuel D. Rapid diagnosis of cytomegalovirus pneumonia in marrow transplant recipients by bronchoalveolar lavage using the polymerase chain reaction, virus culture, and the direct immunostaining of alveolar cells. Blood. 1993;81(7):1909-14.

26. Innis MA, Gelfand DH, Sninsky JJ. White TJ, editors. PCR protocols: a guide to methods and applications. San Diego: Academic Press; c1990.

27. Longo MC, Berninger MS, Hartley JL. Use of uracil DNA glycosylase to control carry-over contamination in polymerase chain reactions. Gene. 1990; 93(1):125-8.

28. McCann JD, Margolis TP, Wong MG, Kuppermann BD, Luckie AP, Schwartz DM, et al. A sensitive and specific polymerase chain reaction-based assay for the diagnosis of cytomegalovirus retinitis. Am J Ophthalmol. 1995; 120(2):219-26.

29. Kumano Y, Manabe J, Hamamoto M, Kawano Y, Minagawa H, Fukumaki Y, Inomata $\mathrm{H}$. Detection of varicella-zoster virus genome having a PstI site in the ocular sample from a patient with acute retinal necrosis. Ophthalmic Res. 1995;27(5):310-6.

30. van den Horn GJ, Meenken C, Troost D. Association of progressive outer retinal necrosis and varicella zoster encephalitis in a patient with AIDS. Br J Ophthalmol. 1996;80(11):982-5.

31. Schlingemann RO, Bruinenberg M, Wertheim-van Dillen P, Feron E. Twenty years' delay of fellow eye involvement in herpes simplex virus type 2-associated bilateral acute retinal necrosis syndrome. Am J Ophthalmol. 1996;122(6):891-2. 
32. Chatzoulis DM, Theodosiadis PG, Apostolopoulos MN, Drakoulis N, Markomichelakis NN. Retinal perivasculitis in an immunocompetent patient with systemic herpes simplex infection. Am J Ophthalmol. 1997;123(5):699-702.

33. Garweg J, Bohnke M. Varicella-zoster virus is strongly associated with atypical necrotizing herpetic retinopathies. Clin Infect Dis. 1997;24(4):603-8.

34. Yamamoto S, Pavan-Langston D, Kinoshita S, Nishida K, Shimomura Y, Tano Y. Detecting herpesvirus DNA in uveitis using the polymerase chain reaction. Br J Ophthalmol. 1996;80(5):465-8.
35. Wiedbrauk DL, Werner JC, Drevon AM. Inhibition of PCR by aqueous and vitreous fluids. J Clin Microbiol. 1995;33(10):2643-6.

36. Chodosh J, Gan YJ, Sixbey JW. Detection of Epstein-Barr virus genome in ocular tissues. Ophthalmology. 1996;103(4):687-90.

37. de Boer JH, Verhagen C, Bruinenberg M, Rothova A, de Jong PT, Baarsma GS, Van et al. Serologic and polymerase chain reaction analysis of intraocular fluids in the diagnosis of infectious uveitis. Am J Ophthalmol. 1996;121(6): $650-8$.

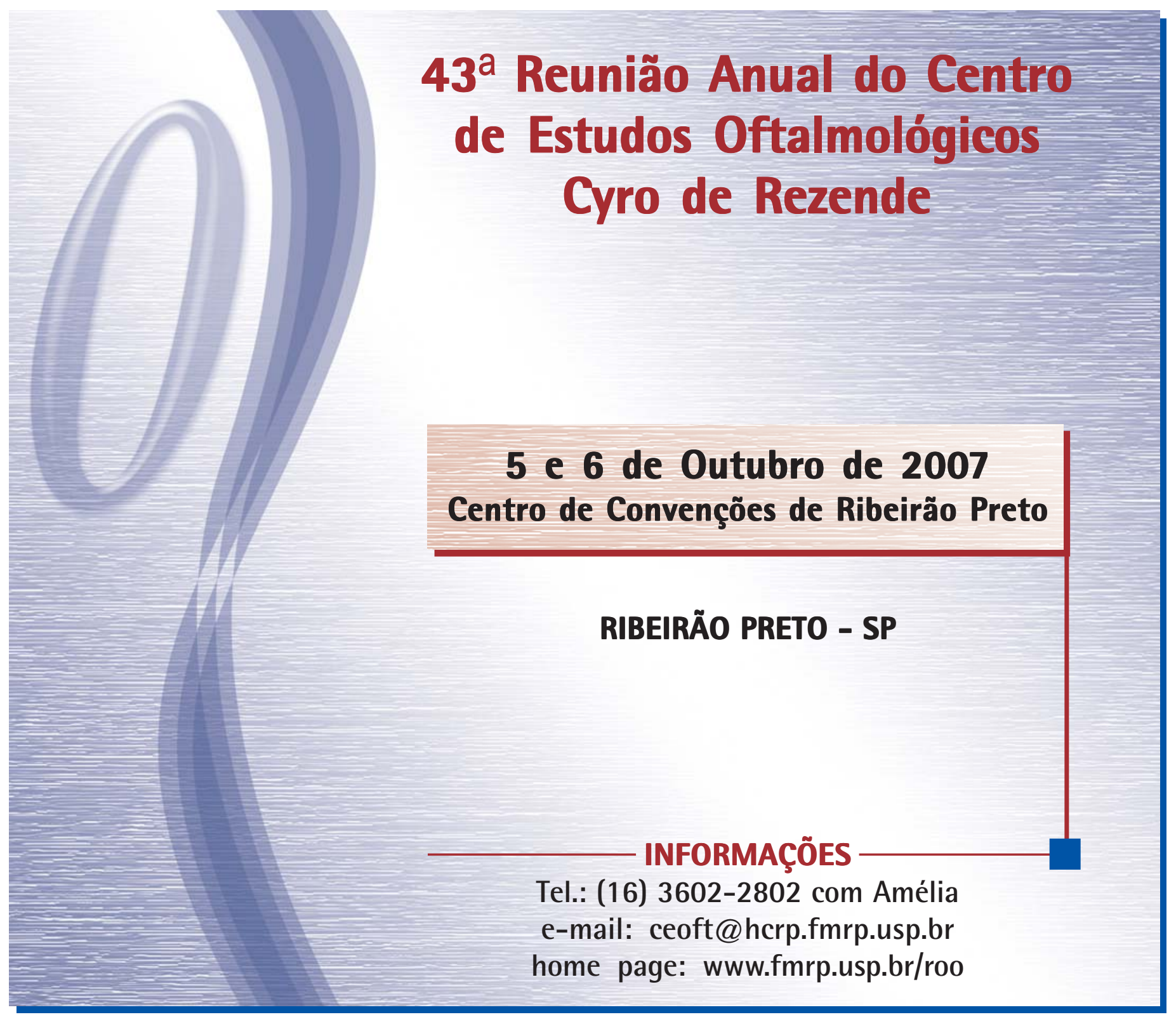

